\title{
Rooftop level rainwater harvesting system
}

\author{
Hayssam Traboulsi ${ }^{1} \cdot$ Marwa Traboulsi $^{2}$
}

Received: 19 November 2014/ Accepted: 21 April 2015/Published online: 7 May 2015

(c) The Author(s) 2015. This article is published with open access at Springerlink.com

\begin{abstract}
Unfortunately, in Lebanon and other countries in the Middle East region, water becomes scarcer than ever before, and over the last decades the demand on domestic water has increased due to population and economic growth. Although rainwater harvesting is considered to be a safe and reliable alternative source for domestic water, the inconvenience or impracticalities related to the cost and space needed for the construction of ground or underground storage tanks makes this practice not widely common in rural areas and rarely implemented in urban cities. This paper introduces a new technique to rainwater harvesting which can be easily used in both rural and urban areas: it collects and stores rainwater directly in tanks already installed on building roofs and not necessarily in special ground or underground ones. If widely adopted in Lebanon, this technique could help in: (1) collecting around $23 \mathrm{MCM}(70 \%$ of the current deficit in the domestic water supply) of rainwater and thus increasing the available water per $\mathrm{m}^{2}$ of building by $0.4 \mathrm{~m}^{3}$ per year, (2) saving around $7 \%$ of the amount of electric energy usually needed to pump water from an aquifer well and ground or underground tank, and (3) considerably reducing the rate of surface runoff of rainwater at the coastal zones where rainwater is not captured at all and goes directly to the sea.
\end{abstract}

Keywords Middle East · Lebanon - Rainwater harvesting $\cdot$ Climate change $\cdot$ Water shortage

Hayssam Traboulsi

hayssam.traboulsi@gmail.com

1 Faculty of Agronomy and Veterinary Sciences, Lebanese University, Dekwaneh, Beirut, Lebanon

2 Department of Mechanical Engineering, American University of Beirut, Beirut, Lebanon

\section{Introduction}

The optimization of the use of all available water resources and the increase of the efficiency of the water distribution networks are considered to be the essential steps to follow if the water shortage problem being faced in water scarce countries is to be solved. The population increase and economic growth in the Middle East region will inevitably lead to a dramatic decrease in available water per capita per year. Climate change is also seen as another challenge that will greatly reduce natural water resources in the region (Lebanon is no exception) by affecting precipitation, temperature, evaporation, relative humidity and solar radiation. The research activities to find nonconventional water resources have noticeably increased during the last decade for its importance in a country future water budget. It is reported in Mourad et al. [1] that the reuse of grey water in toilet flushing can save up to $35 \%$ of drinking water. The technique of rainwater harvesting, which is a technique to collect and store rainwater in a ground/underground reservoir for later domestic or agriculture use, is considered one of the most important nonconventional water resources in the world. It is widely used to alleviate problems of water shortage [2]. For example, Australians broadly collect rainwater in ground (underground) tanks due to the water shortage in rural areas. Up to $50 \%$ of the needed water for toilet flushing, laundry, hot water, and outdoor irrigation in multi-unit residential buildings in Australia can be provided from rainwater harvesting [3]. A significant percentage of the non-potable water needs of multifamily residential buildings in New York City can be supplied with roof harvested runoff [4]. In Syria, it was found that a potential increase in water availability due to rainwater harvesting could be as much as $35 \mathrm{MCM}$ [5]. A maximum of $15.5 \mathrm{MCM}$ of water can be collected from 


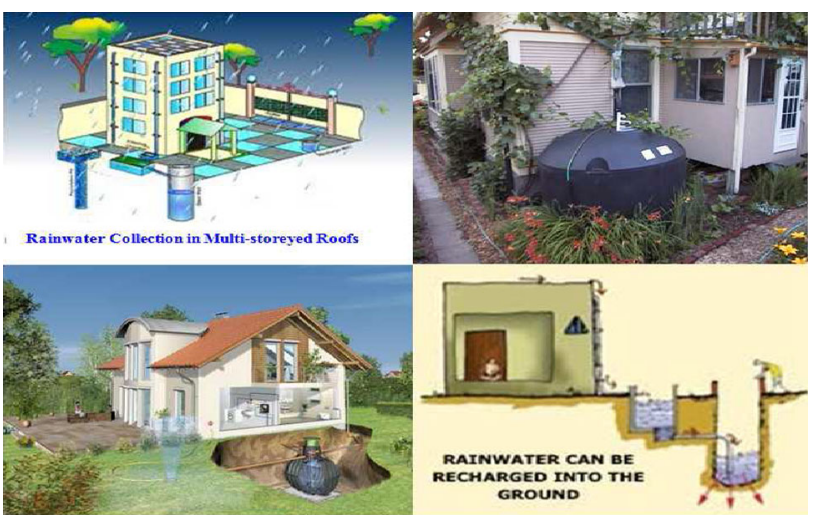

Fig. 1 Schematic diagrams for rainwater harvesting systems

roofs of residential buildings in Jordan [6]. Similar studies showed that using rainwater harvesting can give high percentage of potable water saving in Sweden, Brazil, and UK [7, 8]. There are also some rainwater harvesting techniques that can help in reducing soil erosion. In Syria, for example, large semi-circular bunds are used to reduce erosion of agricultural soil in the Badia rangeland, which is located in the eastern part of Syria with an annual rainfall less than $100 \mathrm{~mm}$, by 16-53\% [9]. Rainwater harvesting can be also used to feed ponds (reservoirs) during the wet season using topographical maps and GIS [10, 11]. Figure 1 shows the designs for the mostly used techniques in rainwater harvesting system in urban and rural areas. Rainwater is collected from rooftops/paved surfaces, filtered and then charged into wells or stored in tanks situated at the ground/underground level for later consumption [12].

These methods for rainwater storage should always be accompanied with a water pressure pump (see Fig. 2) if the collected rainwater is to be consumed at a level higher than the one for rainwater storage tank, which is the case of all modern residential buildings in Lebanon and elsewhere in the region. Thus, households would not be able to benefit from the harvested water unless they have permanent access to electric energy sources whenever water is needed. However, this is not the case in Lebanon and many other countries in the Middle East where electricity is as scarce as water.

In contrast, this paper shows an unconventional technique for rainwater harvesting in which the rainwater is collected and directly stored in already existing roof tanks so that the water pressure pump would not be needed. But, before going into the details of this technique, we first study the potential of harvesting rainwater for domestic use in Lebanon.

\section{The potential of harvesting rainwater in Lebanon}

Lebanon's water resources are under stress. Available water including rivers and springs, storage dams and groundwater (estimated at 2000-2700 MCM per year) exceed projected water demand (about $1800 \mathrm{MCM}$ in 2035), but widespread pollution and substandard water infrastructure restrict the Government's ability to meet water demands in the future. While the current annual expected demand is $1483 \mathrm{MCM}$, the undermining reality of all data on water resources is that Lebanon's four water establishments, combined, are currently exploiting only about 1377 MCM i.e. 106 MCM less than what is potentially needed (see Table 1). The fact that the current expected annual demand on domestic water in Lebanon is around $31 \%$ of the total exploited water would cause around $33 \mathrm{MCM}(31 \% \times 106)$ deficit in the volume of
Fig. 2 The plumbing diagram for a rainwater harvesting system

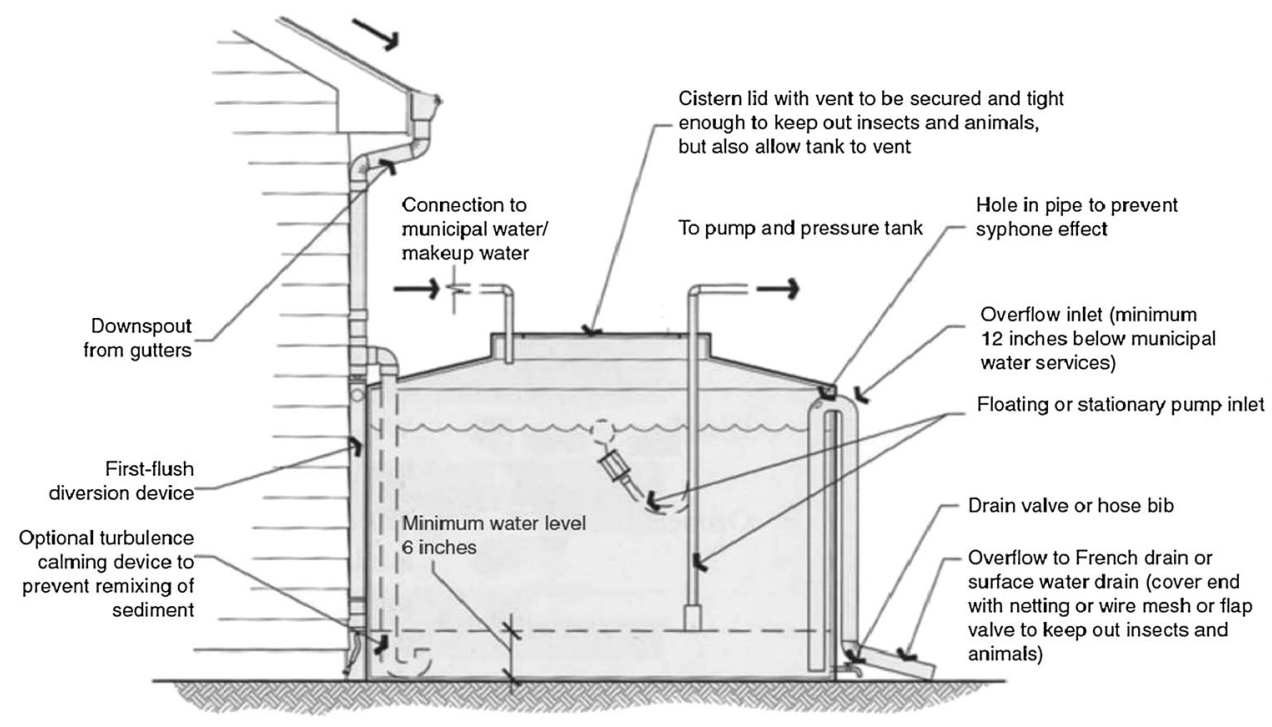


Table 1 The MCM estimated annual water demand by sector (2010-2035)

\begin{tabular}{lrrrrrr}
\hline Sector & 2010 & 2015 & 2020 & 2025 & 2030 & 2035 \\
\hline Domestic & 505 & 460 & 427 & 467 & 512 & 562 \\
Industrial & 152 & 138 & 128 & 140 & 154 & 169 \\
Tourism & 6 & 8 & 10 & 13 & 16 & 21 \\
Irrigation & 810 & 877 & 935 & 983 & 1021 & 1050 \\
Total & 1473 & 1483 & 1500 & 1603 & 1703 & 1802 \\
\hline
\end{tabular}

Source: [13]

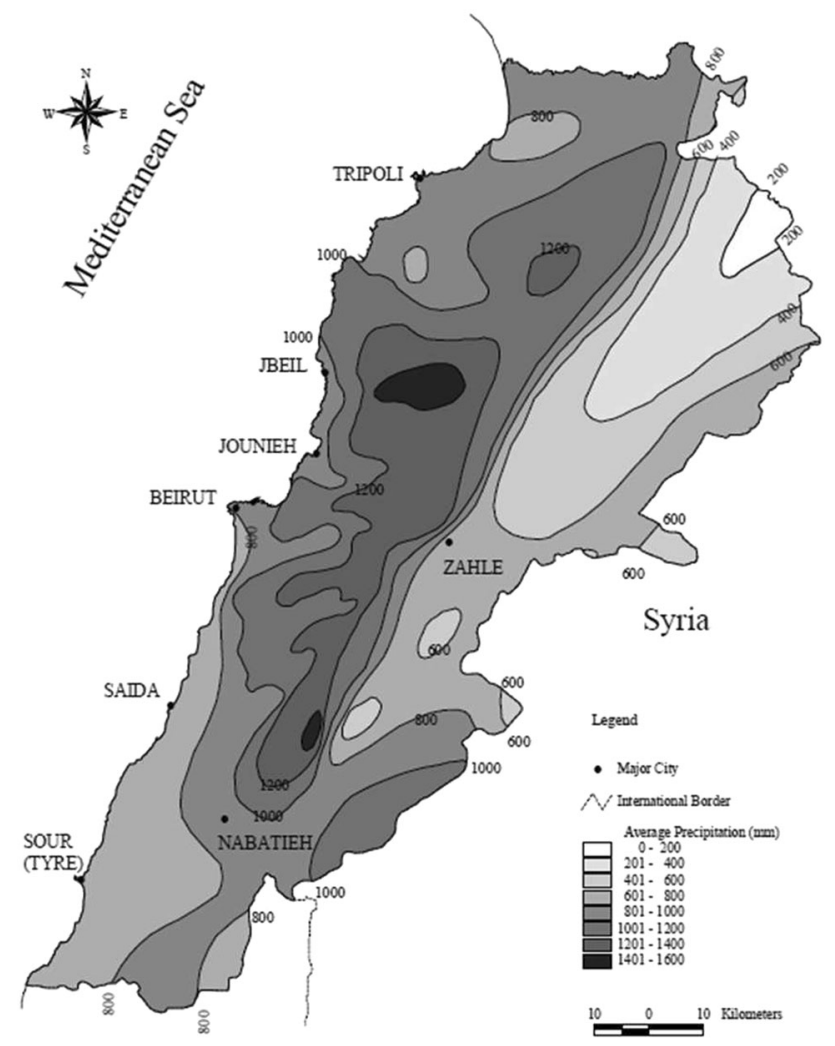

Fig. 3 Climatic zones in Lebanon

water needed for domestic use (460 MCM), and far more in the coming years if alternatives for domestic water resources were not provided [13].

Lebanon could benefit greatly from rainwater harvesting given its Mediterranean climate with an average annual rainfall of $823 \mathrm{~mm}$ although this varies from 700 to 1000 $\mathrm{mm}$ along the coast and from 1500 to $2000 \mathrm{~mm}$ in the mountains decreasing to $400 \mathrm{~mm}$ in the eastern parts and to approximately $200 \mathrm{~mm}$ in the northeast (see Fig. 3). Rain occurs from 80 to 90 days a year, mainly between October and April [14, 15].

To estimate the potential of rainwater harvesting in Lebanon, rainfall data, climatic areas, population, and housing type in each governorate were considered. For roof
Table 2 Average precipitation and population in the Lebanese Governorates

\begin{tabular}{lcll}
\hline Governorate & $\begin{array}{l}\text { Area } \\
\left(\mathrm{km}^{2}\right)\end{array}$ & $\begin{array}{l}\text { Rainfall } \\
(\mathrm{mm} / \mathrm{year})\end{array}$ & $\begin{array}{l}\text { Population } \\
(\text { million })\end{array}$ \\
\hline Mount Lebanon & 1985 & 1200 & 1.97702 \\
North Lebanon & 2024.8 & 1000 & 0.9644 \\
$\begin{array}{l}\text { Beqaa } \\
\text { South Lebanon \& } \\
\quad \text { Nabatiehn }\end{array}$ & 4429 & 600 & 0.57864 \\
$\begin{array}{l}\text { Beirut } \\
\text { Total }\end{array}$ & 1993.4 & 750 & 0.81974 \\
& 19.8 & 600 & 0.4602 \\
\end{tabular}

Table 3 Roof runoff in Lebanon

\begin{tabular}{lllr}
\hline Governorate & $\begin{array}{l}\text { FA } \\
\left(10^{3} \times \mathrm{m}^{2}\right)\end{array}$ & $\begin{array}{l}\text { Rainfall } \\
(\mathrm{mm} / \text { year })\end{array}$ & $\begin{array}{r}\text { HW } \\
(\mathrm{MCM})\end{array}$ \\
\hline Mount Lebanon & 26,349 & 1200 & 12.647 \\
North Lebanon & 11,030 & 1000 & 4.412 \\
South Lebanon \& & 10,417 & 750 & 3.125 \\
$\quad$ Nabatieh & & & \\
Beqaa & 7353 & 600 & 1.764 \\
Beirut & 6128 & 600 & 1.470 \\
Total & 61,277 & & 23.418 \\
\hline
\end{tabular}

water harvesting we follow the methodology detailed in Mourad and Berndtsson [5]. That is the total roof area in each governorate is calculated based on the average area and number of typical houses. The potential rainwater harvesting volume is estimated based on the total roof area, the average annual rainfall, and the runoff coefficient. Then, the increase in domestic water availability per $\mathrm{m}^{2}$ of building as well as the percentage of the potential volume of harvested rainwater of the current annual domestic water deficit in Lebanon are calculated.

Around $60 \%$ of the population in Lebanon live in multiple floor buildings in the costal area that receives an abundant rainfall. Table 2 presents the population as well as the area and average annual rainfall in each of Lebanon's governorates.

The potentially harvested water (HW) for each governorate is estimated by the following equation:

$\mathrm{HW}=R \times A \times K$

where $R$ is the average rainfall in the target governorate, $A$ is the total roof area and $K$ is the runoff coefficient of $80 \%$, which indicates a loss of $20 \%$ of the rainwater that is discarded for roof cleaning and evaporation [6].

The harvested rainwater for each governorate was estimated by Eq. (1). According to Table 3, it is seen that the total potential of harvested water from roofs in Lebanon could reach $23 \mathrm{MCM}$ if we assume that only $50 \%$ of the 


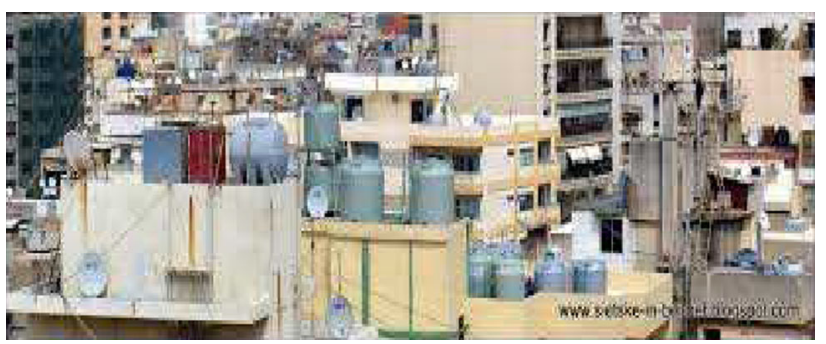

Fig. 4 Roof water tanks

rainfall is effectively harvested. Note that the floor area of residential buildings for each governorate was estimated using the Census of Buildings, Dwellings and Establishments (CBDE) performed by the Central Administration of Statistics in 2004, ${ }^{1}$ which counts 408,515 buildings; 175,661 (43\%) in Mount Lebanon, 73,533 (18 \%) in North Lebanon, 69,448 (17\%) in South Lebanon and Nabatieh, 49,022 (12\%) in Beqaa, and 40,852 (10\%) in Beirut. The floor area (FA) of each building was averaged to $150 \mathrm{~m}^{2}$ in all governorates.

These $23 \mathrm{MCM}$ of rainwater can cover around $70 \%$ of the current deficit in the volume of water needed for domestic use (33 MCM) and increase the available water per $\mathrm{m}^{2}$ of building by $0.4 \mathrm{~m}^{3}$ per year in Lebanon.

\section{System design}

The design of a rainwater harvesting system must take into consideration factors such as the contributing rooftop area, the rainfall patterns, and the anticipated usage as well as the space available for storage, cost and aesthetics.

The catchment area should be calculated based on the footprint created by the roof and not by the square footage of the roof surface. It is the flat roof of residential buildings in our case. The storage tank, which is sometimes called a cistern, is the primary storage component of the system and is usually the most expensive component of the rainwater harvesting system. Material, size, and location of storage tanks are dependent upon the anticipated purposes of the collected rainwater. We use the already existing roof water tanks (see Fig. 4) for the primary storage of the collected rainwater.

The water's use defines the degrees of contaminant removal that may be required. Our rainwater harvesting system is intended for direct domestic use. Thus, a top drain cover having coarse mesh on its sides and a multistage water filter are used to filter out large debris, dust and

\footnotetext{
${ }^{1}$ http://www.cas.gov.lb/index.php/census-of-building-cbde-en. Accessed on: 14/11/14.

bird droppings. A first flush can also be diverted by not activating the system on the first rainfall (see Fig. 5).

The conveyance in our rainwater harvesting system is not as usual as the roof drain conduit, which is usually composed of a series of gutters, downspouts and pipes that conveys precipitation from the roof through the piping and to the cistern. It is rather an ordinary water pipe to pump the accumulated rainwater into the water storage tank through a water filter. The pump used for the conveyance purpose can be as small as the $12 \mathrm{~V}, 10 \mathrm{~W}$ water pumps (see Fig. 6). Solar pumps of this type are available for locations without electricity.

A bypass or overflow pipe is usually necessary for an ordinary rainwater harvesting system so that continuing water flow is directed away from the full water tank to protect the area from erosion. No need for such an overflow pipe in our design as when the roof water tank has reached capacity (i.e. the tank float switch is deactivated), any additional rainwater will be drained to the street (or to a ground/underground storage tank) through the overflow of the roof drain and the pump will be off. The water pump will start pumping if and only if the water level in the storage tank is lower than its maximum and the roof rainwater gauge (the drain float switch) is activated. The outlet pipe, installed above the bottom of the storage tank, is used to supply water to the distribution system that ultimately delivers the captured rainwater to its desired location, e.g. the apartments of the residential building in our case. No need for a pump to provide adequate pressure to draw water for some applications as the gravity will do this job.

In addition to its impact on increasing available water per capita per year, the implementation of our system is simple and does not need any extra space for storage. Its cost is so comparable to buying few cisterns of water during the dry season and even far less than the ordinary rainwater harvesting systems. Next we discuss the expected savings one could achieve through the use of our system in Lebanon.

\section{Expected savings in Lebanon}

The limiting factors to instal rainwater harvesting systems in most residential buildings in Lebanon are the space available for storage, cost and aesthetics. Our technique for rainwater harvesting does not only provide a solution to cut dramatically the cost and keep the aesthetics of buildings, but rather help in reducing the electricity bills of households having access to either aquifer wells or water utility service. The savings that a multifamily residential building could reach through the use of our rainwater harvesting system are discussed using the building example below. 
Fig. 5 Rooftop level rainwater harvesting system

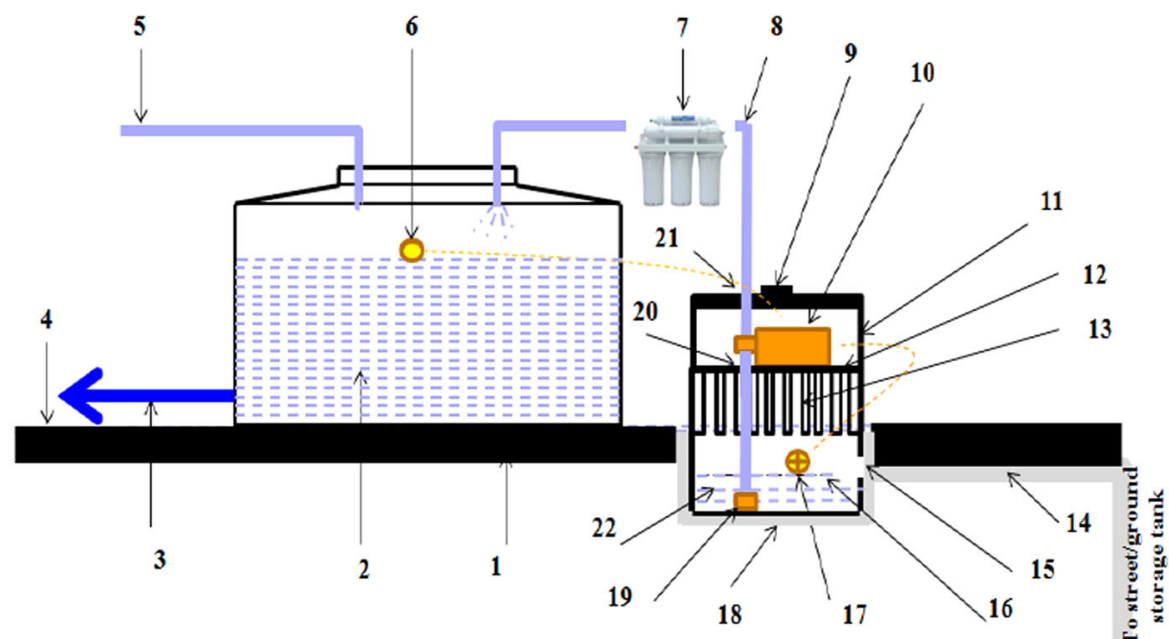

12. Waterpump stand

13. Coarse mesh

14. Drain pipe

15. Drain overflow

16. Overflow level

17. Drain float switch

18. Roof drain

19. Oneway valve directed upward

20. Pipe passing hole

21. Pipe passing hole

22. Rainwater accumulated in the roof drain

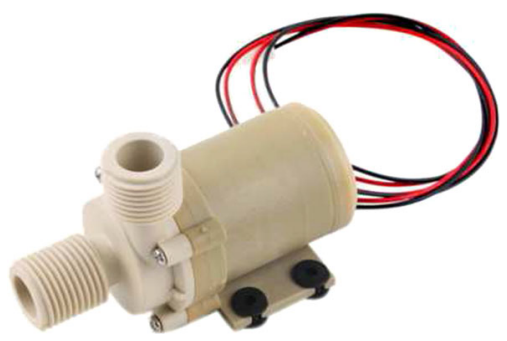

Fig. 6 The water pump
First, the building is located in Beirut. Second, it has a height of $22 \mathrm{~m}$ and a rooftop area of $400 \mathrm{~m}^{2}$. Third, the residents ( 75 persons) of this building rely only on a water well of $150 \mathrm{~m}$ depth for their domestic water supply. Fourth, the average monthly precipitation for Beirut in 2013 was as shown in Fig. 7. The expected amount of water that can be harvested from rainfall each wet month would be as much as shown in Table 4 . Here $80 \%$ of the rainfall is assumed to be effectively collected.
Fig. 7 Average monthly precipitation (2013)

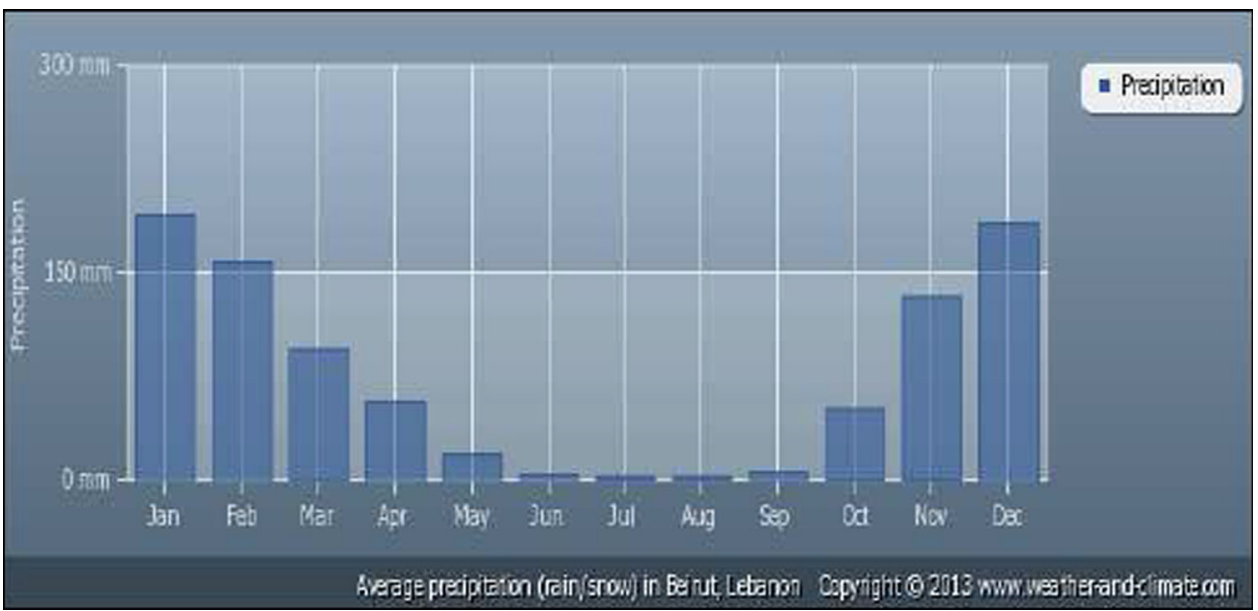


Table 4 The average monthly rainwater collection

\begin{tabular}{lcc}
\hline Governorate & Rainfall (mm/year) & HW $\left(\mathrm{m}^{3}\right)$ \\
\hline January & 180 & 46 \\
February & 155 & 40 \\
March & 70 & 18 \\
April & 40 & 10 \\
May & 20 & 5 \\
October & 30 & 8 \\
November & 90 & 23 \\
December & 180 & 46 \\
Total & 765 & 196 \\
\hline
\end{tabular}

Table 5 The total cost for the rooftop level rainwater harvesting system

\begin{tabular}{lc}
\hline System materials (part no. in Fig. 5) & Cost $(€)$ \\
\hline $1 \times 10$ W 12 V water pump (10) & 20 \\
$2 \times$ Float switch (6, 17) & 17 \\
$1 \times$ Water level control circuit & 9 \\
$1 \times$ Pipe-like drain cap (11) & 25 \\
$1 \times$ Multi-stage water filter (7) & 38 \\
All necessary pipe and fittings & 51 \\
Total material cost & 160 \\
Total labour cost & 94 \\
Total cost & 254 \\
\hline
\end{tabular}

This volume of water increases the availability of domestic water for the residents of this building as much as $196 \mathrm{~m}^{3}$ a year. It serves its residents for 26 days if every resident consumes on average $100 \mathrm{~L}$ a day. It also reduces the rate of power consumption for water pumping of this building by around $7 \%$ a year: the domestic water is only provided from rainwater harvesting and not from the building's aquifer well, and thus, the aquifer pump will not be operating for 26 days a year. Moneywise, this will be equivalent to $149 €$ and $1850 €$ per year, if the same volume of water was to be bought from a public water supply establishment $\left(0.76 €\right.$ per $\left.\mathrm{m}^{3}\right)$ or water tankers $(9.45 €$ per $\mathrm{m}^{3}$ ), respectively. Of course, the unit price of public water supply would be far cheaper if the water establishments in Lebanon could meet the domestic water demand.

While a rainwater harvesting system usually installed at the Xeriscape Demonstration Garden in Edmond in Oklahoma, USA costs around $8500 €$ [12], our rooftop level rainwater harvesting system is far cheaper and costs around $254 €,{ }^{2}$ which could be recovered in one season only.

\footnotetext{
2 The prices of the system parts are obtained from Amazon.com.

Table 5 shows the system materials and total costs for the rooftop level rainwater harvesting system.

\section{Conclusion}

Rainwater harvesting can be an important alternative to increase available domestic water and sustain groundwater. Lebanon could harvest around $23 \mathrm{MCM}$ of rainwater a year and thus cover around $70 \%$ of the current deficit in the domestic water supply estimated at $33 \mathrm{MCM}$. The proposed rainwater harvesting system is intended to collect and store rainwater in the already existing roof water tanks. It is far cheaper than the ordinary rainwater harvesting systems as it eliminates the need for a special ground or underground storage tank, submersible pump, first flush diverter and other less expensive materials. It could harvest as much as $196 \mathrm{~m}^{3}$ a year if installed on a rooftop of 400 $\mathrm{m}^{2}$ and receives an average yearly rainfall of $765 \mathrm{~mm}$ like the city of Beirut in Lebanon.

Open Access This article is distributed under the terms of the Creative Commons Attribution 4.0 International License (http:// creativecommons.org/licenses/by/4.0/), which permits unrestricted use, distribution, and reproduction in any medium, provided you give appropriate credit to the original author(s) and the source, provide a link to the Creative Commons license, and indicate if changes were made.

\section{References}

1. Mourad AK, Czemiel-Berndtsson J, Berndtsson R (2011) Potential fresh water saving using greywater in toilet flushing in Syria. J Environ Manag 92(10):2447-2453

2. Cheng CL, Liao MC (2009) Regional rainfall level zoning for rainwater harvesting systems in Northern Taiwan. Resour Conserv Recycl 53(8):421-428

3. Eroksuz E, Rahman A (2010) Rainwater tanks in multi-unit buildings: a case study for three Australian cities. Resour Conserv Recycl 54(12):1449-1452

4. Basinger M, Ontalto F, Lall U (2010) A rainwater harvesting system reliability model based on nonparametric stochastic rainfall generator. J Hydrol 392(3-4):105-118

5. Mourad K, Berndtsson R (2011) Potential water saving from rainwater harvesting in Syria. J Water Manag Res (VATTEN) 67(2):113-117

6. Abdulla AF, Al-Shareef AW (2009) Roof rainwater harvesting systems for household water supply in Jordan. Desalination 392(1-3):195-207

7. Villarreal EL, Dixon A (2005) Analysis of a rainwater collection system for domestic water supply in Ringdansen Norrkping, Sweden. Build Environ 40(9):1174-1184

8. Fewkes A (1999) The use of rainwater for WC flushing: the field testing of a collection system. Build Environ 34(6):765-772

9. Alkouri I (2011) The effect of using big semi circular bunds technique of water harvesting on controlling the erosion of agricultural soil in Syrian Baddia (Mahassa). In: Lecture presented in the international workshop entitled Optimal use of Available Water Resources, Al-Baath University, Syria 
10. Al-Adamat R, Diabat A, Shatnawi G (2010) Combining GIS with multicriteria decision making for sitting water harvesting ponds in Northern Jordan. J Arid Environ 74(3):1471-1477

11. Farajalla N, Brown P (2010) Rainwater harvesting cluster development plan, empowering municipalities through local economic development. http://www.ebaladiyat.com/Library/Files/ Case. Accessed 14 Nov 2014

12. Stringer A, Vogel J, Lay J, Nash K (2011) Design of rainwater harvesting systems in Oklahoma, Oklahoma Cooperative Extension Service Fact Sheets-BAE-1757, Oklahoma State University. http://osufacts.okstate.edu. Accessed 14 Nov 2014
13. MOEW (2010) National Water Sector Strategy: Baseline, Republic of Lebanon, Ministry of Environment

14. Ministry of Agriculture (2012) National Action Programme to Combat Desertification. National Council for Scientific Research, Beirut-Lebanon, pp 12-60

15. Safi S, Abi-Saleh B (1999) National Action Programme to Combat Desertification. Republic of Lebanon, Ministry of Environment 